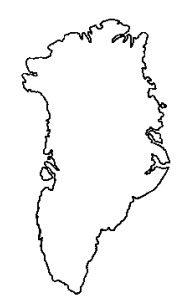

\title{
Continued geophysical and petroleum geological activities in West Greenland in 1995 and the start of onshore exploration
}

\author{
Flemming G. Christiansen, Kevin J. Bate, Gregers Dam, \\ Christian Marcussen and T. C. R. Pulvertaft
}

The 1995 summer season saw continued petroleum activities in West Greenland, both onshore and offshore. The activities took place both as major geological and geophysical projects led by the Geological Survey of Denmark and Greenland (GEUS) and financed jointly by the Government of Greenland, Minerals Office and the Danish State, and as a new commercial exploration programme with the Canadian oil company grønArctic Energy Inc. as operator.

During the past 3-4 years the attitude that the onshore Nuussuaq Basin is mainly of interest as a source of important data for evaluating the offshore exploration potential has changed to the view that it has considerable exploration possibilities of its own (Christiansen et al., 1995). In addition to major systematic studies of the sedimentology, stratigraphy and organic geochemistry of the Cretaceous and Tertiary succession (e.g. Christiansen et al., 1996; Dam \& Sønderholm, 1994, in press; Nøhr-Hansen, 1993, $1994 \mathrm{a}, \mathrm{b}$, in press) a number of encouraging breakthroughs have been important in focusing on local exploration possibilities:

- discovery of surface oil seeps in 1992-94 (an area of at least $8 \times 5 \mathrm{~km}$ ) and in cores from the Marraat-1 drill hole on southern Nuussuaq in 1993 (Christiansen, 1993; Christiansen et al., 1994a, b, 1995);

- discovery of wet gas in 1994 during drilling for hard minerals at Serfat on the north coast of Nuussuaq (Dam \& Nøhr-Hansen, 1995);

- documentation by refraction and reflection seismics in 1994 that the sedimentary succession under at least part of Nuussuaq is much thicker (more than $8 \mathrm{~km}$ ) than previously expected (Christiansen et al., 1995).

In the areas offshore West Greenland new seismic data acquired by the Geological Survey of Greenland (GGU) in 1990-92 and by Nunaoil A/S in 1994 have led to a greatly improved understanding of the regional structure of the sedimentary basins and revealed new plays for petroleum exploration (see reviews by Chalmers et al., 1993, 1995). This has especially been the case for the Fylla area (Fig. 1) where the existence of large structures with direct hydrocarbon indicators in the form of flat-spots have attracted the attention of industry (Bate et al., 1994, 1995). However, the exploration possibilities are not restricted to the
Fylla area, and several recent studies have provided interesting results that could be important guides for exploration in the coming years:

- interpretation of seismic data west of Disko suggesting that subvolcanic plays could be explored (Whittaker, 1995, this report; Whittaker et al., 1996);

- reinterpretation of the $\log$ and other data from the Kangâmiut-1 well indicating that wet gas was encountered but never properly tested (Bate, 1995, in press);

- identification of large, but complex, transpressional structures in the area around the Ikermiut-1 well that could provide traps for hydrocarbons (Chalmers et al., 1995).

The many encouraging results and ideas on exploration possibilities both onshore and offshore West Greenland encouraged the Government of Greenland, Minerals Office and the Danish State to provide funding for major projects related to petroleum exploration. The projects carried out in 1995 include seismic acquisition in the fjords of the Disko - Nuussuaq area and the offshore area west of Disko (DiskoSeis 95), seismic acquisition off southern West Greenland (IkerSeis 95, KangaSeis 95, ExtraSeis 95), drilling of a stratigraphic well on Svartenhuk Halvø, and a detailed study of the cores drilled by grønArctic Energy Inc. during their exploration.

\section{Seismic programme}

The seismic programme was carried out with Nunaoil $\mathrm{A} / \mathrm{S}$ as operator using the Danish Navy vessel Thetis which has been adapted to accommodate seismic equipment. Acquisition took place in the period 23 June - 3 August 1995 and a total of $3745 \mathrm{~km}$ seismic data were collected (Fig. 1). The data are presently being processed by Robertson Research International Limited (formerly Simon Petroleum Technology) (DiskoSeis 95) and Spectrum Energy and Information Technology (IkerSeis 95, KangaSeis 95, ExtraSeis 95).

\section{DiskoSeis 95}

The main aim of the DiskoSeis 95 survey was to document thick sedimentary successions in the fjords and bays 

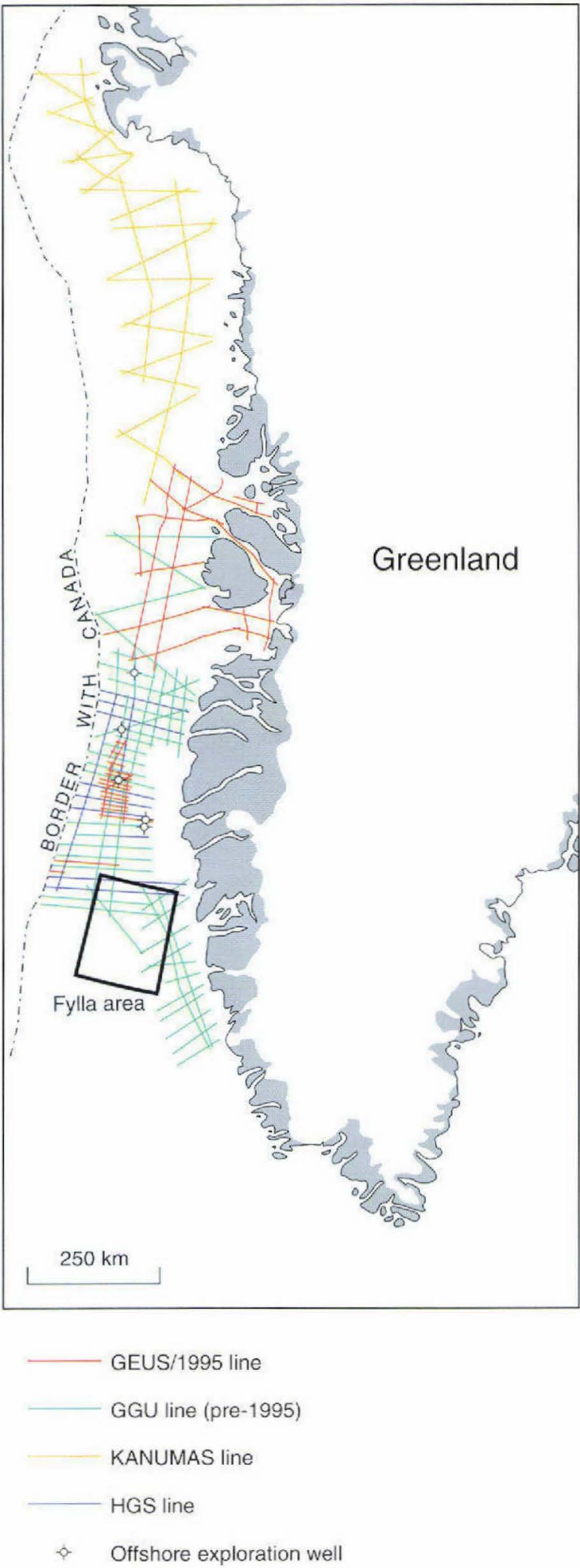

Fig. 1. Location of offshore seismic lines in West Greenland. around Disko and Nuussuaq and to study the structural development of the Nuussuaq Basin (Figs 1,2). Very thick sedimentary successions in half-grabens have previously been documented offshore North-West Greenland (see Whittaker \& Hamann, 1995) and along the south coast of Nuussuaq (Christiansen et al., 1995), and are also indicated by significant negative anomalies on newly acquired satellite and airborne gravity data in the Disko Bugt area.

The DiskoSeis 95 survey was also extended to areas of possible interest for exploration west of Disko (Figs 1, 2) to test if the use of a longer streamer $(4.5 \mathrm{~km})$ could provide more information on the sediments underlying the volcanics than observed by Whittaker (1995) in his study of older seismic data.

Table 1. Technical data from the gronArctic well GANE \#1

$\begin{array}{ll}\text { Well name: } & \text { grønArctic Nuussuaq Eqalulik \#1 } \\ & \text { (GANE \#1) }\end{array}$

Operator: $\quad$ grønArctic Energy Inc., Calgary, Alberta, Canada

Drill contractor: Petro Drilling Ltd., Halifax, Nova Scotia, Canada

Locality:

Aaffarsuaq valley, Nuussuaq, West Greenland

Co-ordinates: $70^{\circ} 28^{\prime} 25^{\prime \prime} \mathrm{N}, 54^{\circ} 00^{\prime} 40^{\prime \prime} \mathrm{W}$

Elevation: $114 \mathrm{~m}$ a.s.1.

Well spud date: 10 July 1995

Termination: 6 August 1995

Rig type:

Total depth: Longyear 44 diamond core drill, adapted mining rig

Hole diameter: $707 \mathrm{~m}, \sim 100 \%$ core recovery 0-202 m: $96.0 \mathrm{~mm}$ (HQ rods), 202-510 m: $75.8 \mathrm{~mm}$ (NQ rods), 510-707 m: $60 \mathrm{~mm}$ (BQ rods)

Core diameter: 0-202 m: $63.5 \mathrm{~mm}$, 202-510 m: $47.6 \mathrm{~mm}$, 510-707m: $36.5 \mathrm{~mm}$

Status: Plugged and abandoned

Main target:

Structural Marraat-type prospect (oil generated from Tertiary deltaic source rock. Tertiary or Cretaceous sandstone reservoir)

Formations drilled: Lower Tertiary volcanics $(500 \mathrm{~m})$, Lower Tertiary and ?Cretaceous siliciclastic sediments ( $207 \mathrm{~m}$ )

Hydrocarbons: Some oil bleeding from core in volcanics; some oil impregnation in sandstones, some gas under pressure in sandstones 


\section{KangaSeis 95, IkerSeis 95, ExtraSeis 95}

The plan for the KangaSeis 95 survey was mainly to acquire a more dense grid of seismic data over the Kangâmiut Ridge. The Kangâmiut-1 well, drilled in 1976 by Total Grønland Olie on the western flank of this ridge, recorded a wet gas kick at a depth of $3694 \mathrm{~m}$ (Bate, 1995). All planned seismic lines were acquired.

It was also hoped to acquire more data in the area west of the Ikermiut-1 well where complex compressional structures are known but where the seismic coverage is limited. However, the vestis (Danish for 'west ice') had not completely retreated from the area in the period when Thetis was available, so only a limited part of the survey was carried out. As a consequence of this change of plans some additional data (ExtraSeis 95) were shot farther to the south over a little known area west of the Fylla structural complex (Fig. 1).

\section{Drilling of stratigraphic well on Svartenhuk Halvø}

The Umiivik-1 stratigraphic slim-core well on Svartenhuk Halvø was drilled in the period 21 August - 15 September 1995. GEUS was operator for the well which was drilled by grønArctic Energy Inc. under the terms of a turn-key contract with the Government of Greenland, Minerals Office.

The main aim of the bore hole was to obtain information on the sedimentology and stratigraphy of the basal part of the marine Upper Cretaceous mudstones, and if possible to document evidence for an oil-prone source rock of Cenomanian - Turonian age. The well reached the planned depth of $1200 \mathrm{~m}$ after having penetrated a thick succession of marine shales with several thick dolerite dykes and sills. The presumed underlying non-marine succession was not reached. Results from the Umiivik-1 well are presented separately by Bate \& Christiansen (this report).

\section{Drilling of commercial wells (grønArctic Energy)}

In the summer of 1995 the first commercial oil exploration wells for almost 20 years were drilled in Greenland with the Canadian company grønArctic Energy Inc. as operator. In May 1995 grønArctic Energy Inc. and Platinova $\mathrm{A} / \mathrm{S}$ were granted an exclusive exploration licence for a $1692 \mathrm{~km}^{2}$ large area covering western Nuussuaq (Fig. 2). grønArctic began their exploration programme with the drilling of three slim-core holes to depths between 400 and $900 \mathrm{~m}$.

Detailed results from the drilling are at present confidential but general information has been released by grøn-

Arctic Energy Inc. and the Mineral Resources Administration for Greenland (see Tables 1-3). GEUS carried out the well site geological description and sampling, and is carrying out an analytical programme for grønArctic Energy Inc. Results from this programme may be released after 1 April 1997.

\section{GANE \#1 and GANK \#1}

These wells are situated in the Aaffarsuaq valley, approximately 10 and $15 \mathrm{~km}$ respectively east-south-east of GGU's Marraat-1 well (Figs 2,3). The main target in both wells was a Marraat type play, i.e. Maastrichtian - Lower Paleocene channel or turbidite sandstone reservoir with a deltaic source rock of similar age, within a structural or stratigraphic trap. Both wells are situated in a little known area some kilometres south-east of the area where oil has previously been documented at the surface (Christiansen et al., 1995, 1996).

\section{Table 2. Technical data from the grønArctic well} GANT \#1

Well name:

Operator:

Drill contractor:

Locality:

Co-ordinates:

Elevation:

Well spud date:

Termination:

Rig type:

Total depth:

Hole diameter:

Core diameter:

Status:

Main target:

Formations drilled:

Hydrocarbons:
grønArctic Nuussuaq Tunorsuaq \#1 (GANT \#1)

grønArctic Energy Inc., Calgary, Alberta, Canada

Petro Drilling Ltd., Halifax, Nova Scotia, Canada

Tunorsuaq valley, Nuussuaq, West Greenland

$70^{\circ} 42^{\prime} 70^{\prime \prime} \mathrm{N}, 53^{\circ} 36^{\prime} 02^{\prime \prime} \mathrm{W}$

$\sim 440 \mathrm{~m}$ a.s.l.

14 July 1995

11 August 1995

Longyear 50 diamond core drill, adapted mining rig

$901 \mathrm{~m}, \sim 100 \%$ core recovery

0-249 m: $96.0 \mathrm{~mm}$ (HQ rods),

249-901 m: $75.8 \mathrm{~mm}$ (NQ rods)

0-249 m: $63.5 \mathrm{~mm}$,

249-901 m: $47.6 \mathrm{~mm}$

Plugged and abandoned

Structural Serfat-type prospect (oil/ condensate generated from mid-Cretaceous source rock, marine Upper Cretaceous or non-marine Lower Cretaceous sandstone reservoir)

Lower Tertiary and Upper Cretaceous siliciclastic sediments $(901 \mathrm{~m})$

Some gas under pressure in many sandstone units 


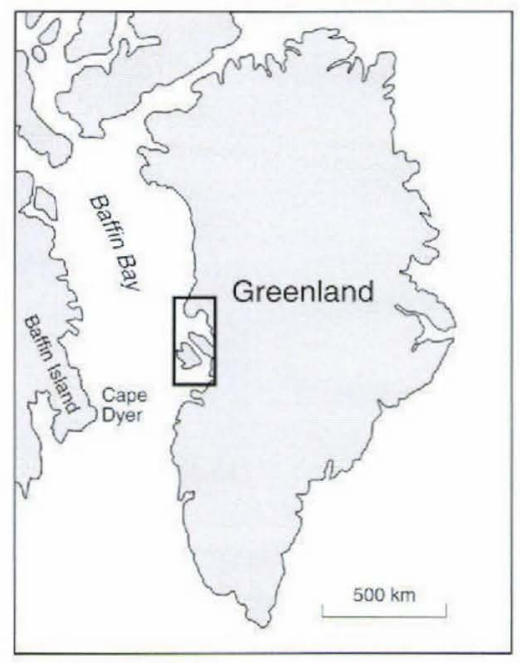

Tertiary basalts and intrusives

Late Maastrichtian-Paleocene sediments

Turonian-Campanian marine shelf sediments

Albian-Campanian fluvio-deltaic sediments

Precambrian

-... Fault

- GEUS seismic lines 1995

† Onshore wells
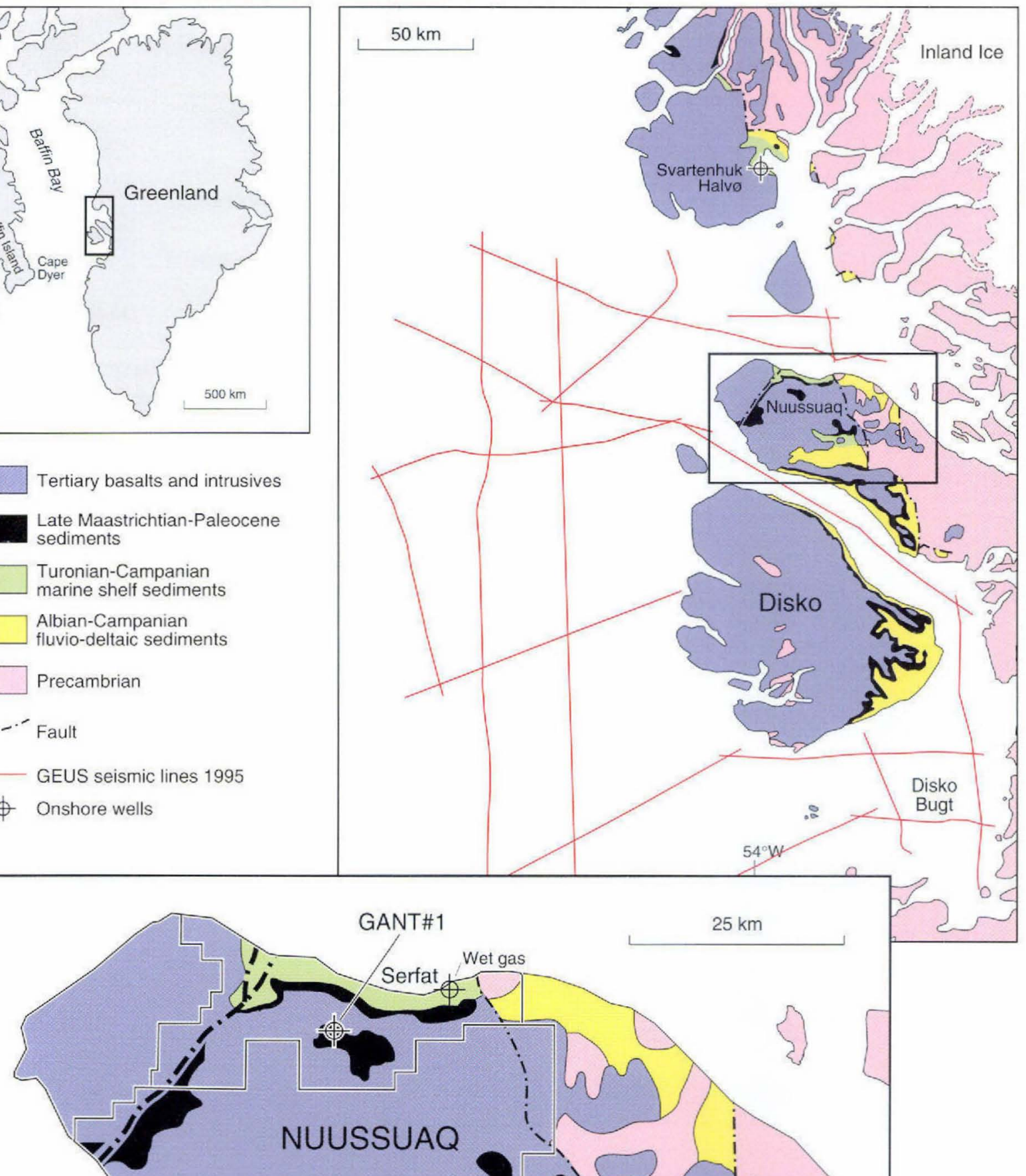

GANW\#1 Live oil at surface Marraat-1

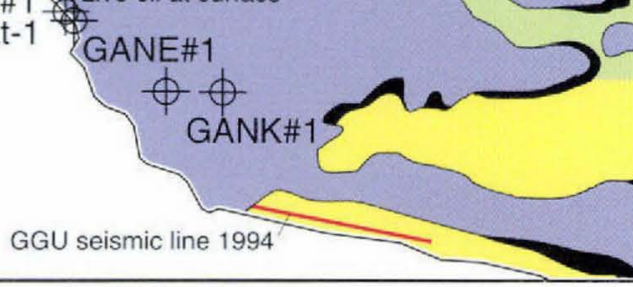

Fig. 2. Map of the Disko - Nuussuaq - Svartenhuk Halvø area showing positions of 1995 offshore seismic lines, wells and grønAretic's licence areas. 


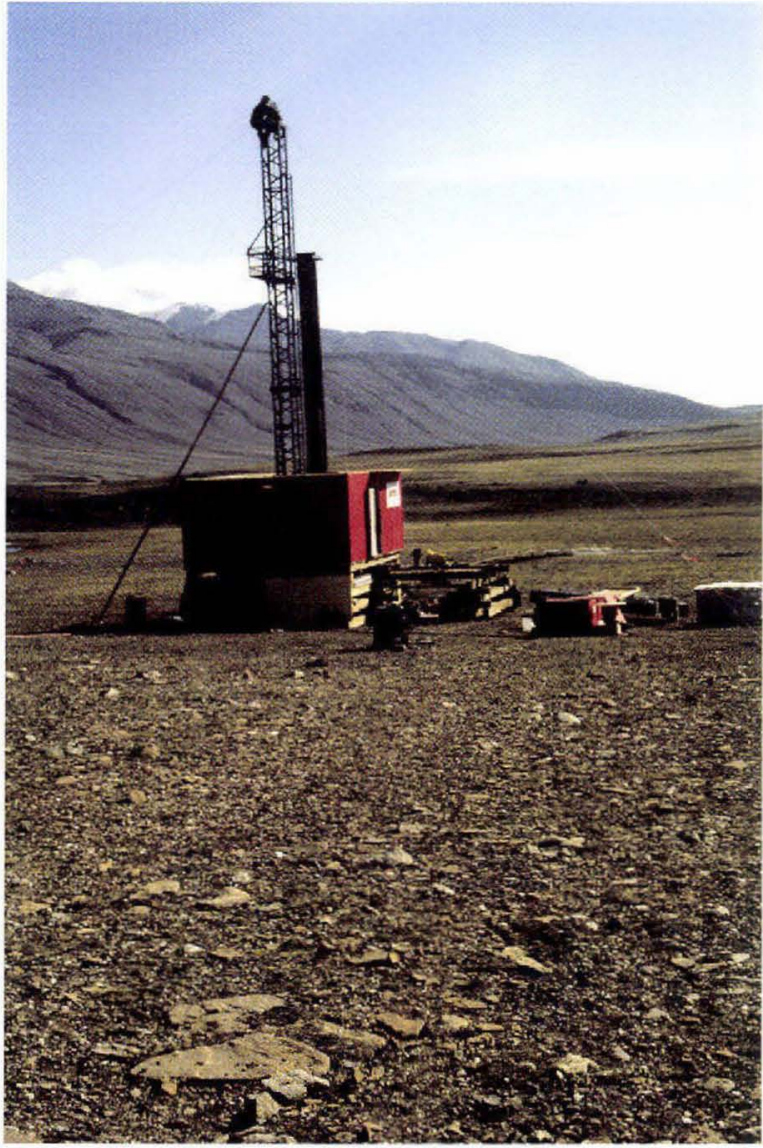

Fig. 3. GANE \#1 drill site in the Aaffarsuaq valley, Nuussuaq.

Both wells were sited on hyaloclastic breccias, the base of which was penetrated at $497 \mathrm{~m}$ in GANE \#1 and at $115 \mathrm{~m}$ in GANK \#1. Oil was identified bleeding from the cores at several levels in the volcanics in which traces of oil are generally common. In the underlying Maastrichtian? Tertiary sedimentary succession gas under pressure as well as oil impregnation was encountered (Fig. 4). Drilling was terminated at depths of $707 \mathrm{~m}$ and $398 \mathrm{~m}$, respectively (Tables 1 and 2).

\section{GANT \#I}

This well is situated in the Tunorsuaq valley (Fig. 2), where a Cretaceous - Tertiary succession similar to that known from the north coast of Nuussuaq is exposed. The main target was a structural play, with marine Cretaceous sandstones as the reservoir unit and an inferred mid-Cretaceous oil-prone source rock. The well was clearly inspired by the discovery of wet gas in a mineral exploration drill hole at Serfat on the north coast of Nuussuaq in the summer of 1994 (see Dam \& Nøhr-Hansen, 1995).
GANT \#1 was sited very close to the Cretaceous-Tertiary boundary and penetrated a succession of Upper Cretaceous marine sediments. The well reached a depth of $901 \mathrm{~m}$ and documented a number of sandstone layers with gas under pressure (Table 3 ).

\section{Future exploration}

Although none of the wells reached the planned depth of $1000 \mathrm{~m}$, grønArctic Energy Inc. is reported to be very encouraged by the results and plans further drilling with a conventional oil exploration rig in 1996. GrønArctic Energy Inc. has applied for additional acreage on Nuussuaq adjacent to its present licence area. Furthermore grønArctic Energy Inc. is negotiating a new exploration licence covering parts of Disko (grønArctic Energy Inc., 1996).

Following on their reconnaissance magneto-telluric survey in 1995, grønArctic has also planned further geologi-

\section{Table 3. Technical data from the gronArctic well GANK \# 1}

$\begin{array}{ll}\text { Well name: } & \text { grønArctic Nuussuaq Kuussuaq \#1 } \\ & \text { (GANK \#1) } \\ \text { Operator: } & \begin{array}{l}\text { grønArctic Energy Inc., Calgary, Alberta, } \\ \text { Canada }\end{array}\end{array}$

Drill contractor:

Petro Drilling Ltd., Halifax, Nova Scotia, Canada

Locality:

Aaffarssuaq valley, Nuussuaq, West Greenland

Co-ordinates:

$70^{\circ} 28^{\prime} 25^{\prime \prime} \mathrm{N}, 53^{\circ} 53^{\prime} 25^{\prime \prime} \mathrm{W}$

Elevation:

$91 \mathrm{~m}$ a.s.l.

Well spud date:

11 August 1995

Termination:

28 August 1995

Rig type:

Total depth:

Longyear 44 diamond core drill, adapted mining rig

Hole diameter:

$398 \mathrm{~m}, \sim 100 \%$ core recovery

0-168 m: $96.0 \mathrm{~mm}$ (HQ rods),

168-398 m: $75.8 \mathrm{~mm}$ (NQ rods)

Core diameter: $\quad 0-168 \mathrm{~m}: 63.5 \mathrm{~mm}$,

$168-398 \mathrm{~m}: 47.6 \mathrm{~mm}$

Status:

Main target:

Plugged and abandoned

Structural Marraat-type prospect (oil generated from Tertiary deltaic source rock, Tertiary or Cretaceous sandstone reservoir)

Formations drilled: Lower Tertiary volcanics (115 m), Lower Tertiary and ?Cretaceous clastic sediments $(273 \mathrm{~m})$

Hydrocarbons: Traces of oil in volcanics and sediments, some gas under pressure in sandstones 


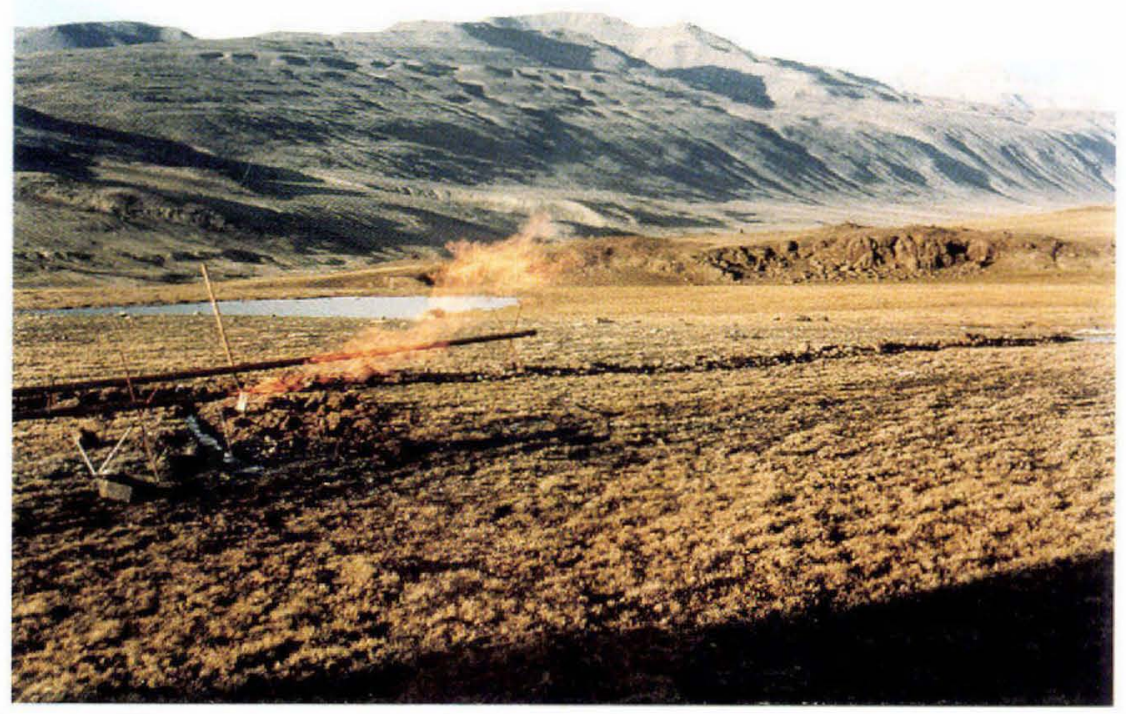

Fig. 4. Flaring gas at GANE \#1 in the Aaffarsuaq valley, Nuussuaq.

cal and geophysical activities in 1996. The new activities are planned to include airborne magnetics and gravimetrics, a magneto-telluric survey, satellite imagery, microbial prospecting and slim hole drilling (grønArctic Energy Inc., 1996).

Acknowledgements. Funding for GEUS hydrocarbon-related projects was provided by the Government of Greenland, Minerals Office and the Danish State through the Mineral Resources Administration for Greenland.

\section{References}

Bate, K. J. 1995: Pressure indicators from the sedimentary basin of West Greenland. Open File Ser. Gronlands geol. Unders. 95/13, $31 \mathrm{pp}$.

Bate, K. J. in press: Interpretation of the basal section of well Kangâmiut-1 offshore southern West Greenland. Geological Survey of Denmark and Greenland, Report.

Bate, K. J., Whittaker, R. C., Chalmers, J. A. \& Dahl-Jensen, T. 1994: Fylla complex - possible very large gas reserves off S.W. Greenland. Oil \& Gas .J. 92, 79-82.

Bate, K. J., Whittaker, R. C., Chalmers, J. A. \& Dahl-Jensen, T. 1995: The Fylla structural complex: possible very large gas reserves offshore southern West Greenland. Rapp. Gronlands geol. Unders. 165, 22-27.

Chalmers, J. A., Pulvertaft, T. C. R., Christiansen, F. G., Larsen, H. C., Laursen, K. H. \& Ottesen, T. G. 1993: The southern West Greenland continental margin: rifting history, basin development, and petroleum potential. In Parker, J. R. (ed.) Petroleum Geology of Northwest Europe, Proceedings of the 4th Conference, 915-931. London: Geological Society.

Chalmers, J. A., Dahl-Jensen, T., Bate, K. J. \& Whittaker, R. C. 1995: Geology and petroleum prospectivity of the region offshore southern West Greenland - a summary. Rapp. Gronlands geol. Unders. 165, 13-21.
Christiansen, F. G. 1993: Disko Bugt Project 1992, West Greenland. Rapp. Gronlands geol. Unders. 159, 47-52.

Christiansen, F. G., Bojesen-Koefoed, J. \& Nytoft, H. P. 1994a: Organic geochemistry of oil-impregnated cores from the Marraat-I well, Nuussuaq, West Greenland - comparison with surface samples. Open File Ser. Gronlands geol. Unders. 94/8, $26 \mathrm{pp}$.

Christiansen, F. G., Dam, G. \& Pedersen, A. K. 1994b: Discovery of live oil at Marraat, Nuussuaq. West Greenland - field work, drilling and logging. Rapp. Gronlands geol. Unders. 160. 57-63.

Christiansen, F. G., Marcussen, C. \& Chalmers, J. A. 1995: Geophysical and petroleum geological activities in the NuussuaqSvartenhuk Halvø area 1994 - promising results for an onshore exploration potential. Rapp. Gronlands geol. Unders. 165 , $32-41$.

Christiansen, F. G., Bojesen-Koefoed, J., Dam, G., Nytoft, H. P., Pedersen, A. K., Larsen, L. M. \& Pulvertaft, T. C. R. 1996: The Marraat oil discovery on Nuussuaq, West Greenland: evidence for a latest Cretaceous-earliest Tertiary oil source rock in the Labrador Sea-Melville Bay region. Bull. Can. Soc. Petrol. Geol. 44, 39-54.

Dam, G. \& Nøhr-Hansen, H. 1995: Sedimentology and stratigraphy of the sediments from cores drilled by Falconbridge Ltd. in 1994 at Serfat, northern Nuussuaq, West Greenland. Open File Ser: Gronlands geol. Unders. 95/8, 16 pp.

Dam, G. \& Sønderholm, M. 1994: Lowstand slope channels of the Itilli succession (Maastrichtian-Lower Paleocene), Nuussuaq, West Greenland. Sediment. Geol. 94, 49-71.

Dam, G. \& Sønderholm, M. in press: Sedimentological evolution of a fault-controlled Early Paleocene incised valley system, Nuussuaq Basin, West Greenland. In Shanley, K. W. \& McCabe, P. J. (ed.) Relative role of eustasy, climate, and tectonism in continental rocks. Soc. Econ. Paleont. Mineral. Spec. Publ.

grønArctic Energy Inc. 1996: Corporation Profile January 1996, Calgary: grønArctic Energy Inc., 20 pp. 
Nøhr-Hansen, H. 1993: Upper Maastrichtian?-lower Paleocene dinoflagellate cysts and pollen from turbidites in the Itilli region, Nuussuaq, central West Greenland. Rapp. Gronlands geol. Unders. 159, 81-87.

Nøhr-Hansen, H. 1994a: Dinoflagellate cyst biostratigraphy of the Upper Cretaceous black mudstones in central Nuussuaq, West Greenland. Open File Ser. Gronlands geol. Unders. 94/12, 26 pp.

Nøhr-Hansen, H. 1994b: Dinoflagellate cyst biostratigraphy of the Upper Cretaceous black mudstones between Niaqornat and Ikorfat on the north coast of Nuussuaq, West Greenland. Open File Ser. Grønlands geol. Unders. 94/14, 24 pp.

$\mathrm{N} \wp \mathrm{hr}-\mathrm{Hansen}, \mathrm{H}$. in press: Upper Cretaceous dinoflagellate cyst stratigraphy, onshore West Greenland. Bull. Gronlands geol. Unders. 170, $104 \mathrm{pp}$.

Whittaker, R. C. 1995: A preliminary assessment of the structure, basin development and petroleum potential offshore central West Greenland. Open File Ser. Grфnlands geol. Unders. 95/9, $33 \mathrm{pp}$.
Whittaker, R. C. \& Hamann, N. E. 1995: The Melville Bay area, North-West Greenland - the first phase of petroleum exploration. Rapp. Grønlands geol. Unders. 165, 28-31.

Whittaker, R. C., Bate, K. J., Chalmers, J. A., Marcussen, C., Christiansen, F. G. \& Pulvertaft, T. C. R. 1996: Basin development and structure of the area covered by Tertiary basalts offshore Central West Greenland - implications for subvolcanic plays. Abstract, Amer. Ass. Petrol. Geol. Annual Meeting, San Diego, May 19-22, 1996.

F. G. C., G. D., C. M. \& T. C. R. P., Geological Survey of Denmark and Greenland, Copenhagen

K. J. B., Geological Survey of Denmark and Greenland, Copenhagen. Present address: Robertson Research International Ltd, Llanhros, Llandudno, LL30 1SA, U.K. 